\title{
Krekó, Péter and Attila Juhász. 2017. The Hungarian Far Right: Social Demand, Political Supply, and International Context. Stuttgart: ibidem Press. 267 pp.
}

\author{
Reviewed by Steven Jobbitt, ${ }^{*}$ Lakehead University
}

Charting the dramatic rise of the far right in Hungary since the late 1990s, this comprehensive study by Péter Krekó and Attila Juhász draws on an extensive body of original research to explain both the popular appeal and electoral successes of two key Hungarian parties: the radical right Jobbik (Jobbik Magyarországért Mozgalom ['Movement for a Better Hungary']), and the populist right Fidesz (Fiatal Demokraták Szövetség ['Alliance of Young Democrats']). As the authors note at the very beginning of the book, the consolidation of illiberal politics in Hungary has over the last decade garnered a great deal of attention from Hungarian and foreign scholars, as well as from international media, and for good reason. The "meteoric rise" of Jobbik since 2006, coupled with the growing extremism of Hungary's ruling Fidesz party, demand explanation, especially in light of the fact that together the two parties captured, in both the 2010 and the 2014 general elections, roughly seventy percent of the popular vote. Focusing in particular on Jobbik and its supporters, and taking the broader European context into consideration, Krekó and Juhász argue that the dramatic shift in contemporary Hungarian politics needs to be examined from two critical points of view: social demand and political supply. Although Jobbik's popularity had already begun to wane by the time they published their study in 2017, the authors contend that a detailed analysis of Jobbik's appeal and relative political competencies opens up new perspectives on the specific nature of the far right in Hungary, and this, in turn, helps us to better understand Fidesz's decision to adopt, in the wake of their electoral victories in 2010 and 2014, increasingly populist, nativist, and authoritarian approaches.

Stressing the need to gauge and understand the social demand behind the popularity of the far right in Hungary, Krekó and Juhász employ an evaluation criterion called the Demand for Right-Wing Extremism index (DEREX), a measurement tool developed by analysts at the Political Capital Institute (a policy research and consulting institute founded in Budapest in 2001, of which Krekó is executive director and Juhász is deputy director). A percent-based indicator, DEREX provides a quantitative overview of responses to opinion-poll surveys that gauge the attitudes and dispositions of respondents in four main categories: prejudices and welfare chauvinism; right-wing value orientation; antiestablishment sentiment; and fear, distrust, and pessimism (40). Though they do not ignore social and economic factors entirely, Krekó and Juhász contend that ideological and psychological elements, as well as emotional factors, need to

*sjobbitt@lakeheadu.ca

(cc) BY

ULIS D-ferle
New articles in this journal are licensed under a Creative Commons Attribution 4.0 International License.

This journal is published by the University Library System of the University of Pittsburgh as part of its D-Scribe Digital Publishing Program and is cosponsored by the University of Pittsburgh Press 
Jobbitt, Steven. "Krekó, Péter and Attila Juhász. 2017. The Hungarian Far Right: Social Demand, Political Supply, and International Context. Stuttgart: ibidem Press. 267 pp." Hungarian Cultural Studies. e-Journal of the American Hungarian Educators Association, Volume 13 (2020) DOI: 10.5195/ahea.2020.400

be foregrounded and accounted for if an accurate picture of social demand for far-right politics is to be understood.

Examining data collected between 2002 and 2009, the authors note that Jobbik's explosion onto the political scene in 2009-2010 "was preceded by a sharp rise in the demand for right-wing extremism" (46). Pointing to the results of surveys, they note that Hungarians expressed a very high level of prejudice against minorities, and were especially prone to antiimmigrant sentiments "spiced" with welfare chauvinism (a term that refers to the perceived "parasitical" nature of immigrants and their demands on state resources) (48). Also notable were indicators that suggested a favorable view of authoritarian practices and ideas, and which revealed a desire for a strong state and high levels of security. At the same time, respondents expressed a growing distrust of democracy and of political elites, and high levels of antiestablishment sentiments. According to DEREX, between 2002 and 2009 the percentage of Hungarian voters expressing far-right attitudes doubled from ten percent to twenty-one. As they point out, this means that "ideologically and psychologically more than one-fifth of the population over the age of fifteen became susceptible to far-right thinking" (46). The social demand for far-right politics and solutions may have fluctuated since 2009, but it nevertheless has remained consistently high, and it goes a long way to explaining the popularity of Jobbik in the 2010 and 2014 elections.

Though the detailed analysis of DEREX's quantitative data provides nuanced information regarding the social demand for right-wing radicalism in Hungary since the early 2000s, this data alone has its limitations when it comes to explaining the Hungarian far right as a political phenomenon. As Krekó and Juhász note, "social demand is a necessary but far-from-sufficient condition for the [political] consolidation of the far right" (63). In order to fully comprehend Jobbik's electoral successes, the two authors argue convincingly that we need also to consider what they call political supply, a concept that takes both political competency and organizational capacity into consideration. Simply put, social demand alone cannot ensure the political success of the far right. There needs also to be an organized party apparatus in place, one that is capable of articulating a clear ideological position amidst a field of competing political platforms, and which is capable of harnessing the existing demand for far-right political action.

Jobbik, as it turns out, was just such a party. Founded in 2003, in the 2006 general elections Jobbik ran alongside István Csurka’s antisemitic MIÉP (Magyar Igazság és Élet Pártja ['Hungarian Justice and Life Party']) but broke with this older party after garnering only two percent of the popular vote. Capitalizing on both the declining popularity of MIÉP (which had been founded by Csurka in 1993) and the scandals and public outrage that plagued the government of Ferenc Gyurcsány in the immediate wake of the 2006 elections, Jobbik harnessed a growing wave of right-wing energy in Hungary, and they rode it to their first significant electoral success in 2009, when the party secured fifteen percent of the popular vote in the election to the European Parliament. As Krekó and Juhász point out, although Jobbik also benefitted from Fidesz's increasingly radical rhetoric and posturing, the party made skilled use of the Internet and emergent social-media platforms to publicize their ideas and generate popular support. Beyond responding in a coherent way to the global financial crisis in 2008-2009, Jobbik was also the first party in Hungary to politicize the so-called "Roma problem," and so could frame it on their own terms, thus helping to carve out a very distinguishable and immediatelypopular niche on the right. Jobbik's electoral breakthrough in 2009 , moreover, followed by their capture of seventeen percent of the vote in the 2010 general elections, sent a clear message to voters and their political opponents that Jobbik had become a legitimate party. Political 
"offensives" directed against them by the left and by Fidesz further legitimized the party in the eyes of Jobbik's growing supporters. Even their opponents had to recognize Jobbik as a legitimate party backed by a popular movement (104).

In the second half of the book, Krekó and Juhász go into considerable detail with respect to Jobbik's political development after 2010, and though there is nothing very new here from either a descriptive or an analytical point of view, it is nevertheless a fine summary of Jobbik's organizational structure and political platform up to 2017. What is likely to be of more interest to students of the far right in Hungary is the critical analysis of Jobbik supporters that the authors offer in the first section of their study. Drawing on the data they collected to determine the social demand for the far right in Hungary since the early 2000s, Krekó and Juhász reject the widespread belief that Jobbik supporters largely come from the underprivileged segments of society. Far from fitting the stereotype of "unemployed or low-income, undereducated people living in the villages of Northeastern Hungary," they found that the average Jobbik supporter is a "middle-class man with some academic qualification" who has not experienced any significant social or economic precarity (86). Noting that the average Jobbik supporter no doubt fears losing his (or her) social position, they conclude that most of those amongst Jobbik's base are not a part of what other scholars have called "the losers of modernization" (33). Generally young, educated, and hypermasculine, the average Jobbik supporter "speaks the language of the youth [and] has a rebellious, antiestablishment stance" (85). Driven by ideological and sociopsychological needs, Jobbik's supporters identify with the party primarily for "symbolic and identity-related reasons" (86).

Given Jobbik's softening of its party position leading up to the 2014 elections and their pronounced decline since the book was published in 2017, some potential readers may wonder whether the analysis offered by Krekó and Juhász is still relevant. The authors, in fact, address this very question early on in their book, noting not only that Jobbik cleared a path for Orbán's authoritarian shift (especially in the wake of the migrant crisis in 2015), but also that the social demand that fueled Jobbik's rise and electoral successes has by no means dissipated. Though the party has lost support in recent years (in part because of its attempts to appear more moderate to voters in the 2014 elections), the energy that fueled its "meteoric rise" persists, which is a factor that Fidesz has capitalized on in recent years.

Even though the present volume does not always deliver on its promise to situate its analysis in an international context, The Hungarian Far Right is grounded in a solid understanding of existing critical and comparative literature on the far right in Europe, and for this reason alone it is an important and timely study. Given that, as late as 2007, the Hungarian far right was considered to be "the weakest in Europe" (66), it is imperative that scholars develop and adopt complex interdisciplinary tools and methods to better analyze and narrate this phenomenon, and not only in Hungary. This study by Krekó and Juhász goes a long way to answering some of the key questions related to the rise and popular success of the Hungarian far right over the last decade, and it will no doubt prove useful to scholars from different fields working not only on Hungary and Europe more generally, but also on case studies and comparative analyses from around the world. 